\title{
Storytelling and Cultural Learning An Expatriate Manager's Narratives of Collaboration Challenges in a Multicultural Business Setting
}

Wilczewski, Michał; Søderberg, Anne-Marie; Gut, Arkadiusz

Document Version

Accepted author manuscript

Published in:

Learning, Culture and Social Interaction

DOI:

10.1016/j.Icsi.2019.04.007

Publication date:

2019

License

CC BY-NC-ND

Citation for published version (APA):

Wilczewski, M., Søderberg, A-M., \& Gut, A. (2019). Storytelling and Cultural Learning: An Expatriate Manager's Narratives of Collaboration Challenges in a Multicultural Business Setting. Learning, Culture and Social Interaction, 21, 362-377. https://doi.org/10.1016/j.Icsi.2019.04.007

Link to publication in CBS Research Portal

\section{General rights}

Copyright and moral rights for the publications made accessible in the public portal are retained by the authors and/or other copyright owners and it is a condition of accessing publications that users recognise and abide by the legal requirements associated with these rights.

\section{Take down policy}

If you believe that this document breaches copyright please contact us (research.lib@cbs.dk) providing details, and we will remove access to the work immediately and investigate your claim. 


\section{Storytelling and Cultural Learning: An Expatriate Manager's Narratives of Collaboration Challenges in a Multicultural Business Setting}

\section{Michał Wilczewski, Anne-Marie Sederberg, and Arkadiusz Gut}

Journal article (Accepted manuscript*)

\section{Please cite this article as:}

Wilczewski, M., Søderberg, A-M., \& Gut, A. (2019). Storytelling and Cultural Learning: An Expatriate Manager's Narratives of Collaboration Challenges in a Multicultural Business Setting. Learning, Culture and Social Interaction, 21, 362-377. https://doi.org/10.1016/j.lcsi.2019.04.007

DOI: 10.1016/.l.lcsi.2019.04.007

* This version of the article has been accepted for publication and undergone full peer review but has not been through the copyediting, typesetting, pagination and proofreading process, which may lead to differences between this version and the publisher's final version AKA Version of Record.

Uploaded to CBS Research Portal: May २०२०

(C) 2019. This manuscript version is made available under the CL-BY-NC-ND 4.0 license http://creativecommons.org/licenses/by-nc-nd/4.0/ 
Wilczewski, M., Søderberg, A.-M., \& Gut, A. (2019). Storytelling and cultural learning-An expatriate manager's narratives of collaboration challenges in a multicultural business setting. Learning, Culture and Social Interaction, 21, 362-377. doi:10.1016/j.lcsi.2019.04.007

\section{Storytelling and cultural learning-An expatriate manager's narratives of collaboration challenges in a multicultural business setting}

Authors' names and affiliations:

Michał Wilczewski ${ }^{\mathrm{a}, \mathrm{b}}$

${ }^{\text {a}}$ Faculty of Applied Linguistics, University of Warsaw, Warsaw, Poland

Address: ul. Szturmowa 4, 02-678 Warsaw, Poland

${ }^{b}$ Department of Management, Society and Communication, Copenhagen Business School, Frederiksberg, Denmark

Address: Dalgas Have 15, DK 2000 Frederiksberg, Denmark

e-mail address: m.wilczewski@uw.edu.pl

Anne-Marie Søderberg ${ }^{\mathrm{c}}$

${ }^{\mathrm{c}}$ Department of Management, Society and Communication, Copenhagen Business School, Frederiksberg, Denmark

Address: Dalgas Have 15, DK 2000 Frederiksberg, Denmark

e-mail address: aso.msc@ cbs.dk

\section{Arkadiusz Gut ${ }^{\mathrm{d}}$}

${ }^{\mathrm{d}}$ Department of Philosophy, The John Paul II Catholic University of Lublin, Lublin, Poland

Address: Al. Racławickie 14, 20-950 Lublin, Poland

e-mail address: kupisa@kul.lublin.pl

\section{Corresponding author:}

Michał Wilczewski

Faculty of Applied Linguistics, University of Warsaw, Poland

ul. Szturmowa 4, 02-678 Warsaw, Poland

e-mail address: m.wilczewski@uw.edu.pl

telephone: (+48) 696410776

'Declarations of interest: none' 


\section{Storytelling and cultural learning-An expatriate manager's narratives of collaboration challenges in a multicultural business setting}

This paper focuses on cultural learning processes in an international business context. The empirical material is an in-depth narrative interview with a European expatriate manager who emplots challenging cultural encounters in an Asian subsidiary of a Western European multinational company. We seek turning points and discoveries in her stories to show how and what she learned from her critical incidents. We found that the new business and cultural context posed a huge challenge during the early stages of her assignment and that prior (explicit) knowledge and international experience did not ensure smooth collaborations. Successful collaborations required creating new context-specific (tacit) knowledge embedded in organizational culture and locals' behaviors. We found that extrapolating from social interactions led to cultural misinterpretations and inhibited cross-cultural interactions and learning, but continued interactions led to better understandings of cultural others' behaviors as their attributions could be renegotiated. Moreover, we found transformative potential of storytelling for expatriate postexperiential learning. We contribute methodologically to the narrative approach in cross-cultural research. We found that collecting stories by the interviewer who shares a nationality, language, and culture with the interviewee may impose an ethnocentric lens on the experiences related and limit the interviewee's reflection on cross-cultural communication and collaboration.

Keywords: cultural learning; cross-cultural collaboration; in-depth interview; narrative analysis; expatriate; multinational company

\section{Introduction}

Globalization has opened new grounds for international business collaborations between people with different cultural, linguistic, economic, and social backgrounds. Crosscultural management research asserts that cultural knowledge and agility are crucial for expatriates' successful adaptation to a host culture (Lenartowicz, Johnson, \& Konopaske, 2014; Yamazaki \& Kayes, 2007). According to prior research and recent research reviews (e.g., Manuti, Pastore, Scardigno, Morciano, \& Giancaspro, 2015), learning to navigate multicultural business contexts is viewed as the core capacity of international managers and hence a strategic asset for the company's competitiveness by reaching the global learning objective (Hocking, Brown, \& Harzing, 2007). In turn, the lack of cross-cultural competencies has long been emphasized as a key cause of expatriate failure (Hampden-Turner \& Trompenaars, 2000). 
Much prior research has focused on conceptualizing cross-cultural competencies (Caligiuri \& Tarique, 2012) and measuring dimensions of cultural intelligence (Ang et al., 2007; Thomas et al., 2008). Such tests often rely on self-reports rather than on empirical observations of social interaction in cultural encounters. Many efforts have also been invested in developing required skills and providing cultural knowledge through cross-cultural training programs offered before departure (Bird \& Mendenhall, 2016; Caligiuri \& Tarique, 2012). But there are few context-sensitive studies that explore how the capacity to function in culturally diverse situations is created (Morris, Savani, Mor, \& Cho, 2014), for example, how and what expatriates actually learn from cross-cultural collaborations in a specific workplace context.

This exploratory empirical study expands upon previous narrative research on cross-cultural collaboration between Western expatriate managers and professionals in an Asian context (Gertsen \& Søderberg, 2011). Its main aim is to examine how and what a European female expatriate manager from a Western European multinational company (MNC) learned through her social interactions with local personnel on an international assignment in an Asian subsidiary between 2011 and 2015. Moreover, the study aims to capture the influence of the storytelling process on furthering expatriate learning.

We draw on narrative inquiry in order to deepen our understanding of how this expatriate manager perceived and retrospectively interpreted critical events from her cross-cultural collaborations. We look at what she learned from them and how she adjusted her behavior and judgments to the situational conditions. First, we conduct a narrative analysis of the rich empirical material with a focus on turning points (peripeteia) in her stories, her emotional reactions in situ and when telling about challenging situations, and her discoveries (anagnorisis) (cf., Gertsen \& Søderberg, 2011). Second, we discuss her learning through the lens of a recently published fourfold taxonomy of intercultural learning processes (Morris et al., 2014). This model excels by integrating and extending previous learning frameworks to establish learning processes important from the expatriate's perspective. It also emphasizes the social dimension of cultural learning, which has often been neglected or downplayed (Søderberg, 2017) in more cognition-centered studies of collaboration and learning in international business contexts (e.g., Taras \& Gonzalez-Perez, 2015).

The paper is structured as follows. First, we present the chosen theoretical framework for studying cultural learning from cross-cultural collaborations. Second, we 
describe the research methodology and present a narrative analysis of three stories told by the expatriate manager. We discuss the findings from this context-sensitive study of critical events that trigger cultural learning processes. We conclude that storytelling, which has long been recognized to further cultural learning, could be applied by company mentors as a method to stimulate expatriates' reflection on their cross-cultural interactions.

\section{Theoretical framework}

\subsection{Learning culture}

Before we introduce our understanding of cultural learning, we need to state that we view culture as a social construction that is constantly negotiated (Brannen \& Salk, 2000) and where knowledge (for example about other cultures) is created through social interactions (cf. Damşa \& Ludvigsen, 2016). Learning requires acquiring and using knowledge and therefore we find it important to introduce a distinction between explicit knowledge (or factual, cognitive, declarative knowledge) and tacit knowledge (or implicit, behavioral, experiential, procedural knowledge). Whereas explicit knowledge is codifiable and easily communicated (Nonaka, 1994) across organizational and national boundaries (Kogut \& Zander, 2003), tacit knowledge is acquired through experience, and it is thus highly contextual and culture-specific. It is based on actions, values, and emotions embedded in social situations, and is thus more difficult to articulate and communicate (Lenartowicz et al., 2014). To successfully select an appropriate reaction in an intercultural interaction, an individual needs to extrapolate from the situational context and from his/her particular relationship with the interactant in order to be able to read the interactant's actions appropriately (Lenartowicz et al., 2014).

We consider cultural learning as a process of expanding one's knowledge of cultural dynamics and changing and recalibrating assumptions and perceptual skills (Nardon, Steers, \& Sanchez-Runde, 2011), which is often triggered by a critical interaction (cf. Mezirow, 1991; Shim \& Paprock, 2002). Expanding one's knowledge and understanding of cultural dynamics in a cultural encounter, i.e., an experience resulting from a social interaction between organizational members who differ culturally from one another (Bird \& Mendenhall, 2016; Piller, 2011), allows a person to enhance his/her behavioral repertoire and adjust his/her way of communicating and 
listening in culture-specific contexts. Learning (to navigate) a foreign culture is thus both an implicit and explicit process that is socially grounded. It involves both reflecting on others' assumptions and reactions and critically examining one's own assumptions, beliefs, and emotions (Hsiung, 2008; Mezirow, 1991; Yan Lo-Philip et al., 2015) to address a given situation.

\subsection{Expatriate cultural learning}

Expatriate success highly depends on a learning orientation that entails ongoing learning on international assignment and hence enhances expatriate adaptability (Porter \& Tansky, 1999). Expatriate management research has emphasized the importance of developing the ability to function in situations marked by cultural diversity, i.e., cultural intelligence (Ang \& Dyne, 2008), for expatriates' effectiveness (Armstrong \& Li, 2017; Søderberg \& Worm, 2011) and their cross-cultural adjustment (Ang et al., 2007; Zhang, Wei, \& Zhou, 2017). This capacity is reflected in looking for constructive partnerships across cultural differences (Plum, Achen, Dræby, \& Jensen, 2008). For example, in their study of Danish and Chinese managers in MNC subsidiaries in Hong Kong and China, A.-M. Søderberg and V. D. Worm (2011) have found cultural intelligence and cultural learning crucial for communication and collaboration in culturally complex business contexts, and developed through dialogue by flexible and open-minded people.

Furthermore, prior research has shown that culturally intelligent individuals, inter alia, perform better in multicultural work contexts, adjust better to such contexts and to the host country, make better behavioral attributions - which, being a form of grasping experience, contributes to their explicit learning (e.g., Ang et al., 2007; Ang \& Van Dyne, 2008; Armstrong \& Li, 2017; Søderberg \& Worm, 2011; Templer, Tay, \& Chandrasekar, 2006). Scholars have also related cultural intelligence (besides crosscultural adjustment) to expatriates' decision making, cultural judgment, and job performance (Ang et al., 2007).

Extant literature on expatriate cultural learning has also linked expatriate adjustment and job performance to personality dimensions (Abbe, Gulick, \& Herman, 2008; Caligiuri, 2000b; Dalton \& Wilson, 2000). Specifically, such traits as curiosity, discovery, and open-mindedness (Deardorff, 2006) are considered as constitutive of intercultural competence (Yan Lo-Philip et al., 2015). Cultural learning may be driven by curiosity and fostered by comfort with ambiguity—which makes confusion a less frightening experience (Morris et al., 2014). Also, interpersonal flexibility (or 
agreeableness) has been found to increase interpersonal adjustment, job satisfaction, opportunities for exposure to intercultural interactions, and thereby presumably to intercultural learning (Caligiuri, 2000b; Dalton \& Wilson, 2000; Mol, Born, \& van der Molen, 2005; Shaffer, Gregersen, Ferzandi, Harrison, \& Black, 2006; Tucker, Bonial, \& Lahti, 2004).

Previous empirical studies have applied various theoretical frameworks to explore organizational phenomena, including expatriate learning (for recent reviews, see, e.g., Lenartowicz et al., 2014; Manuti et al., 2015). The most prominent ones are social learning theory (Bandura, 1977) and experiential learning theory (D. A. Kolb, 1984) which view learning as a process embedded in social interaction. According to social learning theory, learning takes place through observing people's behaviors and modeling their positive and negative outcomes (Davis \& Luthans, 1980). The modeling is regulated through: (1) attention —observing some behavior in the environment; (2) retention-remembering the behavior; (3) reproduction-replicating the observed behavior by translating the symbolic representation of the modeled stimuli into behavior; (4) motivation - the behavior is likely to be reproduced if the individual is internally or externally motivated enough to do so (Bandura, 1977, 1986). Social learning theory has been applied, inter alia, to account for a classical four-stage model of expatriate cross-cultural adjustment (involving honeymoon, culture shock, adjustment, and mastery) (Black \& Mendenhall, 1991).

Other studies of expatriate learning (e.g., Armstrong \& Li, 2017; M. Li, Mobley, \& Kelly, 2013; Yamazaki, 2010; Yamazaki \& Kayes, 2004, 2007) and intercultural training (Fowler \& Blohm, 2004; Landis \& Bhawuk, 2004) have focused on experience as the basis for learning and creating knowledge, following an experiential approach to human learning. Experiential learning theory (Joy \& Kolb, 2009; A. Y. Kolb \& Kolb, 2005; D. A. Kolb, 1984) differs from both the cognitive and behavioral approach to human learning - the first emphasizes cognition over affect, whereas the latter denies the prominent role of human experience in his/her learning (D. A. Kolb, Boyatzis, \& Mainemelis, 2000). According to experiential learning theory, knowledge is not treated as a given entity, but as a process that is constantly (re)created through learning, i.e., transforming subjective experiences (one's personal states) and objective (environmental) experiences; because the subjective and objective experiences are interrelated and reciprocally shape each other, learning — similarly to social learning theory - is also viewed as a transaction between the person and the environment (D. A. 
Kolb, 1984). The process is cyclical and iterative, and comprises: (1) concrete experience - encountering a new experience or reinterpreting an existing experience, (2) reflective observation - reflecting on the experience, (3) abstract conceptualizationconcluding from the experience, which leads to the production of explicit knowledge, and (4) active experimentation - applying the new knowledge in a new situation, which leads to a new experience. Accordingly, the theory essentially focuses on an individual's observations as a basis for the production of explicit knowledge to be later tested and applied in new contexts.

In a recent questionnaire study of learning and adjustment of Anglo managers in China, S. J. Armstrong and Y. Li (2017) have applied experiential learning perspective to show that modes of grasping experience (through abstract vs. concrete conceptualization) and transforming experience (through active experimentation vs. reflective observation) are culture-specific. This finding has important implications for expatriate adjustment, as the authors showed that expatriates with higher managerial knowledge and learning styles congruent with those exhibited by the locals adjusted to a higher degree.

In turn, exploring (through surveys and semi-structured interviews) knowledge transfer and application activities of Swedish expatriates in an Australian subsidiary of a transnational organization, J. B. Hocking et al. (2007) have found that expatriates' knowledge applications were influenced by frequent access and communication with the company's headquarters, and that access to local knowledge (about local organization, networks, and culture) had strong influence on their experiential learning. Moreover, their individual learning was facilitated by direct observation and trial-and-error experimentation.

\subsection{Four-fold taxonomy of intercultural learning}

Previous research links expatriate adjustment and communication and collaboration effectiveness in MNCs with cultural intelligence, intercultural competence, and the personality traits of expatriates, but it offers limited insight into expatriate cultural learning in situ, as a result of previous international experiences, cross-cultural preparation, social interaction with cultural others, and finally-retrospective interpretation of events which should not be neglected in view of the research showing that previous international experience determine an expatriate's success on international assignment (e.g., Caligiuri, 2000a; Selmer, 2001). M. W. Morris et al. (2014) propose 
overcoming these limitations using a four-fold taxonomy of intercultural learning processes, which embraces the following:

- Studying-(explicit, effortful) internalizing explicit (codified) knowledge, e.g., learning from books, brochures, and training programs. Studying a foreign culture involves acquiring facts about a language, history, society, cuisine, etiquette, etc. Abstract propositions about a culture can also be internalized during informal talks with other expats. Importantly, such talks are likely to produce generalizations which—on the one hand — may be "useful starting points for learning" a foreign culture, but also "unfortunate stopping points" (Morris et al., 2014 , p. 198) as they lack cultural nuances and may thus lead to misinterpretations of the host country national's behavior.

- Attributional reasoning - (explicit) learning by attributing observed behaviors to motives, beliefs, and intentions in order to interpret people's behaviors and intercultural interactions, e.g., in a workplace, tacit cultural knowledge is created by making sense of employees' behaviors and attributing certain properties to such employees as well as to a specific situation and social relationship. Attributional reasoning allows one to learn about cultural norms by extrapolating from social interactions (e.g., observing how locals behave in given situations). Importantly, in order to create knowledge about cultural norms based on the host country national's behavior, the expatriate needs to go beyond his or her own ethnocentric perspective and interpret the behavior through the host culture's lens. The likelihood of noticing cultural norms is higher for expatriates who are more experienced in the host culture (Morris et al., 2014).

- Social learning - (implicit, automatic) learning how to perform in specific intercultural situations by imitating others' behaviors and non-verbal communication, e.g., learning such procedural knowledge as cultural scripts by imitating the observed sequences of actions that lead to successful outcomes.

- Conditioning - (implicit, automatic) learning by trying different behaviors to find an optimal approach to intercultural interactions, e.g., an expatriate adjusts his/her behavior depending on personal goals and the specific circumstances of a situation, and learning about how appropriate such behavior is by reading others' explicit reactions to such behavior. This process allows one to learn cultural norms through trial and error from feedback delivered by locals. 
The above taxonomy distinguishes two processes that are important from the perspective of an expatriate who learns how to effectively communicate and collaborate in a multicultural setting, but which are not recognized (or only partly) by experiential learning theory and social learning theory. The first one is studying, which is an explicit process of internalizing explicit knowledge; the process is vital for expatriates' learning during the pre-departure and on-site cross-cultural trainings, because it supports further interactional/experiential learning. The second one is social learning which is a tacit process of imitating the observed behaviors; this process is recognized by social learning theory, but because experiential learning theory views observation as a reflective process, it is qualitatively different from tacit social learning as viewed in social learning theory and the 'four-fold taxonomy'. Accordingly, M. W. Morris et al.'s model unfolds as an approach that integrates and extends existing learning frameworks, to form a set of qualitatively different learning processes important from the expatriate's perspective.

The cultural learning model described above will serve as a framework to situate and understand the learning processes that triggered changes in the European manager's behaviors and attitudes as well as her perceptions of her own and others' identities. By seeking to reveal what her stories tell about cross-cultural collaboration, we aim to develop a relationship between experience, cultural identifications, learning processes, and narrative as a sense-making and sense-giving tool (Fleming, 2001; Ivanova-Gongne \& Törnroos, 2017; Søderberg, 2006); sense making is conceptualized here as a process of meaning (re)construction that allows one to "to develop a meaningful framework for understanding the nature of the intended strategic change" (e.g., events, threats, opportunities), whereas sense giving as a "process of attempting to influence the sense-making and meaning construction of others toward a preferred redefinition of organizational reality" (Gioia \& Chittipeddi, 1991, p. 442). In turn, by disclosing how individual experiences were retrospectively interpreted and emplotted, expatriatelocal employee collaboration will be presented from the European expatriate's perspective (cf., Gertsen \& Søderberg, 2010).

Given our aim stated above, we pose the following research questions:

(1) How did the European expatriate manager retrospectively interpret and emplot her collaboration encounters with Asian employees and managers and what did her stories reveal about her cultural learning? 
(2) How did the expatriate position herself in her stories in relation to local personnel and other expatriates?

(3) What was the impact of the exercise of storytelling on the expatriate's learning after repatriation?

\section{Material and methods}

The study is qualitatively oriented to enable the exploration of an individual's intercultural experiences and learning (Spencer, 2011). The empirical material comprises stories collected in 2016 through an in-depth, narrative interview with Anna, a manager who had returned in 2015 from a three and a half year expatriation to an Asian country. She was approached via personal contacts and selected based on two criteria: (1) the interviewee had to be a manager, which entailed daily communication with local personnel, and (2) the interviewee had to work on international assignment for at least one year.

For the analysis we have selected three stories that present Anna's key learning incidents. We read the interview material several times and identified all the turning points and discoveries that could indicate her learning from collaboration with the locals. Having assessed which stories show Anna's learning over time, we arranged the material on a primary timeline (during and after expatriation) and secondary timeline (exposition to cross-cultural collaboration, collaboration failures, and a collaboration success). This procedure resulted in extracting three stories with clear plots and sequencing of events (Gabriel, 2004); narratives of unstructured events were omitted as they were not meaningful enough to capture the narrator's potential learnings. We collected additional information concerning the context of the manager's expatriation, the internal management culture in her home subsidiary, and the MNC's HR practices related to cross-cultural preparation.

We chose narrative inquiry because it may trigger a reflexive understanding of experiences (Gertsen \& Søderberg, 2011, 2010) and stimulates metacognition (Thomas et al., 2008), which is pivotal in cultural learning. Narrative analysis, being highly exploratory in nature (Freeman, 2004), allows one to holistically examine social, cultural, and psychological phenomena (Daiute \& Lightfoot, 2004) such as the means of identity construction and development (Ishihara \& Menard-Warwick, 2018), the presentation of self, socio-cultural meanings and values, and subject positioning 
(Galasiński \& Galasiska, 2005; Hyvärinen, 2008; Saldaña, 2016). Its applicability has been suggested, among others, for HR management with regard to cross-cultural training and development (Gertsen \& Søderberg, 2010), and for the investigation of the degree of managers and employees' acceptance of an MNC's global strategy and their individual interpretations and recontextualizations of a corporate culture (Søderberg, 2015).

Because this qualitative method provides access to a narrator's world (Méndez García, 2017; Pavlenko, 2007), it allows the researchers to give voice to an expatriate's sense making and cultural learning.

\subsection{The MNC}

The case company is a worldwide leader in its industry, reaching one-fifth market share. It has business activities in over 150 countries and several dozens of production sites in over 15 countries on four continents. Although the MNC had previously manufactured goods in the host country, it planned to extend its business activities there by building a new subsidiary. Approximately 150 expatriates were assigned to the host country between 2011 and 2015 to train the local personnel.

For the sake of further analysis, we find it important to briefly describe Anna's home/European subsidiary in which she had been immersed before her expatriation to Asia. In our interview with her, we learned that the organizational structure is highly hierarchical, although the headquarters has sought to introduce more autonomy and to allow more leeway to make decisions at different managerial levels. Nevertheless, the personnel in the European subsidiary tend to remain dependent on a higher level of management, especially with regard to budget decisions. In terms of leadership style, paternalistic leadership with strong discipline and authority (Farh \& Cheng, 2000) is favored in the European subsidiary. Nevertheless, once individuals have become experts in their field, they are given more autonomy, which the personnel in the home subsidiary term an 'expert' style. The home subsidiary remains highly dependent on the headquarters, which entails a relatively high level of control designed to ensure quality. This dependency is also reflected in the stronger supervision of subordinates in the host country. Respect for hierarchy and pushing decision making up the organizational hierarchy are favored.

\subsection{The interviewee - the learner}


Anna (name changed to protect anonymity) is a European manager in her mid-forties. She studied psychology in her home country and completed a postgraduate program in logistics. After completing a full time MBA program at a French business school, Anna was hired by the Western European MNC where she has worked for the last 15 yearsincluding almost four years in France. She also completed a postgraduate program in leadership and personnel management in her home country and a one-year program in industrial engineering in France. Anna declared that she has proficient knowledge of French and very good knowledge of English (the company language).

In 2011, the MNC's headquarters offered Anna a position as an expert in lean manufacturing in a subsidiary that was being built at the time in Asia. In terms of organizational structure, she took a position of a coordinator and belonged to a team of 25 managers who reported directly to a Western CEO of the subsidiary. Anna mentioned to us in the interview that she had been thinking about taking on a long-term international assignment for some time, although she had never considered being expatriated to Asia. Eventually, although going there entailed separation from her family for the first nine months of her expatriation (her child had to complete the school year), she accepted the offer. In her home subsidiary, she had worked with some of the Asian employees with whom she would later collaborate in the host country.

We also learned about Anna's preparation for expatriation. The MNC provided Anna with brochures about the host city and offered her a 'reconnaissance' two-week visit to the city so that she could visit the factory, check the housing conditions, and visit a school for her child. She emphasized the vital role of other expatriates in her preparation. During her initial visit, she met with expatriates who were already working in the host location. They shared their experiences of living in the host country, but, as she emphasized, 'nobody told me how to get prepared for working with [the host nationals]'. Before expatriation, Anna learned about the host nationals from books, the Internet, and her host language teacher - the MNC offered her and her husband a 120hour language course. She continued the language course in the host country with a different teacher who, in addition to teaching her the language, helped her manage everyday matters and explained practical and culture-related problems. Finally, after five months on the assignment, Anna participated in a three-day cross-cultural training course that gave her 'a chance to learn not only [about the host] culture but also about other nationalities'. 
We want to underline all this information about the interviewee's educational background, previous intercultural experiences, and motivations and preparation for moving to a distant cultural location because it shows that Anna as a manager was experienced in dealing with foreigners, had knowledge of at least two foreign languages, had international work experience, and exhibited motivations for and openness to new intercultural experiences. Given these characteristics, we assumed that she had already developed some culturally intelligent ways to maneuver in a culturally distant business culture; cf. previous research combining extraversion, openness to experience, and intercultural experiences to predict such intercultural competences as tolerance of ambiguity, cultural flexibility, and reduced ethnocentrism (Caligiuri \& Tarique, 2012).

\subsection{Local personnel}

Anna's assignments in the host subsidiary, such as coaching, training, and providing support, entailed daily interactions with local employees and managers. Most of these locals had a higher educational background or at least high technical qualifications (within industrial engineering, chemical engineering, etc.). Their collaborations with expatriates were aimed at upgrading their professional skills.

\subsection{The interviewer as a co-author of narratives}

The narrative interview was carried out by an interviewer that shares national background with the interviewee. His role is important because he asked follow-up questions, influencing the storytelling process, and conducted some follow-up questions after the narration phase, which aimed to contextualize the interview material. On the one hand, conducting the interview in Anna's mother tongue allowed Anna to freely tell rich and emotionally laden stories about her cross-cultural collaborations. On the other hand, however, it must be noted that sharing nationality, language, and culture with the interviewer may have caused Anna to take a "home-country" perspective on the events in the host country. Thus, her stories should be treated as such instances of negotiating meanings that allowed Anna to render them understandable to the interviewer "as prescribed by a specific culture" (Koh \& Wang, 2013, p. 9). Accordingly, the narratives presented in the analytical part of this paper should be treated with caution. The instances of potentially biased interpretations of host country nationals' behaviors caused by co-authoring the narratives will be raised in the analyses. 


\subsection{Interview site}

The interview was carried out in the interviewee's residence, which helped make the interviewee feel comfortable. She spoke freely and willingly told her stories, in some cases very personal, emotional, and even dramatic ones.

\subsection{Procedure}

The interview procedure was designed using the recommendations of Bauer and Gaskell M. W. Bauer and G. Gaskell (2000). In the initiation phase, the purpose of the study was disclosed, and the interviewee was assured full confidentiality and anonymity. The interviewer gathered background information such as the interviewee's educational and professional background, previous work and intercultural experience, and motivations for accepting the assignment in the host country. This information helped afterwards to contextualize the stories. Next, an initial topic was presented that was (a) of personal interest - allowing the narrator to develop stories about matters she considered important from her perspective, (b) experiential, and (c) of social significance (Jovchelovitch \& Bauer, 2000). The initial stimulus was to invite the interviewee to tell stories: 'Please, tell me about your experiences with your co-workers in the host country'. Moreover, the interviewee was asked to focus on critical events: 'Can you think of something particularly surprising/frustrating/difficult/positive/thoughtprovoking/challenging?' (Gertsen \& Søderberg, 2011). The interviewer did not evaluate or comment on any parts of the story but rather encouraged the narrator to continue when she paused or hesitated. In the concluding phase, the interviewer asked some why questions and took notes. This informal small talk was once more a source of contextual information.

The interview lasted 115 minutes. It was audio-recorded and subsequently transcribed verbatim. All stories were further translated by the first author into English as literally as possible to faithfully retain the original meaning.

\section{Narrative analyses}

We will analyze each story by discussing how Anna told a story, i.e., how she related her experiences in order to present her own perspective on expatriate-local employees' collaboration (cf., Gertsen \& Søderberg, 2010; Polkinghorne, 1988). Of particular 
interest will be identifying focal points and challenging situations that offered the narrator opportunities for cultural learning. To do so, we sought turning points (termed by Aristotle peripeteia) and discoveries (termed by Aristotle anagnorisis) in the stories told. Peripeteia implies a sudden change in storied events that triggers a reversal of fortune experienced by the characters (Gertsen \& Søderberg, 2011). Identifying critical incidents in Anna's stories, often accompanied by strong emotions or doubt, was meant to reveal the circumstances that lead to changes in her behavior and an increase in her cultural understanding and learning that fostered collaboration (Gertsen \& Søderberg, 2011). In turn, by identifying anagnorisis, i.e., changes from ignorance to knowledge that accompany or follow peripeteia, we aimed to show the narrator's moments of recognition, her discoveries that increased her cultural self-awareness and her awareness of her own identity and the identities of her host country collaborators. Thereby, we wish to show how she became aware of her own role and others' roles, and how this awareness may have furthered cross-cultural collaboration. Previous research has shown that expatriates' active positioning within interactions with other actors may contribute to more successful interactions (Janssens, Cappellen, \& Zanoni, 2006).

Importantly, we have presented our analyses to Anna to ensure that our analysis of her retrospective interpretation of the critical incidents she told us about complies with (or extends) her understanding of them.

\subsection{Story $I$.}

\subsubsection{Exposition: 'Breaking through the hierarchical barrier'}

Anna related in detail her experiences collaborating with three Asian female colleagues whom she coached to take over her position. Anna's tasks involved training higher and middle-level personnel from different departments (department managers, production masters, and specialists) and coaching the three colleagues to teach new production methods to lower-level, monolingual local personnel. Anna termed her function 'transverse' - it was somehow related to all departments and positions in the company. Anna perceived the three colleagues as completely different personalities, yet she viewed them as sharing some common features (a) she felt they needed to be given direct and precise instructions, (b) from her perspective, they showed little initiative and did not contribute to the team with new ideas, and (c) they lacked resources: 
It was really difficult to convince some [local] managers that our method is recognized in our company and it has to be applied. But this problem [managers' resistance] occurred at the managerial level, and the department managers were a completely different story from those three [Asian] colleagues. If you told [them] something, they took it for granted and accepted it. They believed in the method, but they had a problem convincing higherranking managers to implement it, with breaking through that hierarchical barrier.

In turn, Anna perceived the local superiors as resistant. That perception was a source of difficulty for Anna who was focused on the objective of implementing the multinational company's methods. On the other hand, Anna also implied that what she regarded as 'resistance' could be explained by local managers' lack of experience with the MNC and the headquarters' standardization procedures.

\subsubsection{Act I. 'Marking fire extinguishers'-how ambiguity leads to a failure}

Elaborating on her collaboration with the three local subordinates, Anna recalled that they tended to precisely apply her instructions without adaptation to the local context. She expected them to show initiative and independence, but instead they often involved her in their assignments, e.g., marking production halls or designing and equipping offices. Once, Anna was asked to help mark fire extinguishers:

These local [women] took everything I said literally. Imagine that-we have an empty factory that needs equipment and they, my [local] girls, were asked by one production department to mark fire extinguishers according to our company standard. And they replied that they did not know what it should look like and that they would ask Anna... Anna would know for sure [laugh]. And I agreed and called [my home subsidiary] and told them to take pictures of our factory and e-mail them to me so I could show them to the [locals] and tell them to do something similar. And imagine you get a few pictures showing these fire extinguishers that differ from one another in our factory [in the home subsidiary] depending on the surroundings. And I think to myself, 'Ok, I will give them one picture. If they get all three, they will ask Anna [laugh]: Which one shows the standard?' [laugh]. So, I give them the picture and say, 'Listen up, these extinguishers should be something like this, but this is only an example. Take a look at your place, see what it looks like and adopt it to what you see here in the picture'. And you know what?! It turned out that they... copied... exactly what was in the picture. When I entered the production hall and I saw that... I was shocked! It is difficult to describe. It simply did 
not match. That was completely absurd, completely ridiculous. And when I went there, I started to laugh..., in a sense, because I got scared. And I thought to myself, 'I will be blamed for all this. This is me who told them to do that' [laugh]. And this is one of the examples showing that they copied everything they received. They are given an example, so they copy it. There is no such thing as 'I am showing you only an example, some pattern. You can look at it and do something similar, but do it your way by adopting it to your surroundings, right?'. That was another moment when I learned that when I give them something, it had better be concrete, precise, and sketched to the nearest centimeter.

Anna constructed herself as a teacher, coach, and mentor who took care of her subordinates and helped them handle things they were not sure about. She also positioned herself as an expert who shared useful and practical knowledge with local personnel and finally as an intermediary or boundary spanner who transferred knowledge and certain solutions applied in her home subsidiary to different departments in the host subsidiary (hence, Anna delineated her position as 'transverse'). The last task seemed challenging because it required Anna to make decisions about matters about which she was not necessarily competent. When giving her instructions, she seemed to anticipate that the fire extinguishers shown in the photo would be replicated faithfully and, to avoid that, she emphasized that the markings should be adopted to the specificities of the production hall in the host subsidiary. Despite her efforts, there came a turning point in the story (peripeteia) when she realized she had made a mistake believing that her photo would be treated as an example to be modified and adopted and not as a precise template. This situation led Anna to learning, which was accompanied by strong emotions such as shock, (hysterical) laughter, and fear that she would be held responsible for the inappropriate markings. Anna learned that to avoid communication ambiguity, she needed to try harder to deliver precise and unequivocal instructions.

\subsubsection{Act II. 'Tiny footprints'-history repeats itself}

The next part of the story is an anecdote Anna has often told her home friends about her experiences in the host subsidiary. The plot again revolves around standardization processes. According to the headquarters' recommendations, production halls in all subsidiaries had to be marked using the same pattern. This time, Anna was asked to provide a template for marking forklift tracks to separate them from areas for pedestrians who do not wear safety boots. 
They asked me, again, if I had an example of such a track. And, of course, I again called... [laugh] — this was some time after the 'extinguishers' thing, so I was put off guard a little — and I called my colleagues [in the host subsidiary] and I said, 'Take some photos and send them to me, otherwise it will take me ages to explain what it should look like to the locals. I will let them mark it [track] their own way based on that design'. So, my colleagues sent me pictures of the tracks with the footprints painted, and the size needed to be adjusted to the conditions in the [host country] factory, right? But they did it exactly... [Anna restrains herself from bursting into laugher], they printed footprints of this size [Anna cups her hands] and stuck them on the tracks in the production hall. When I went there - and that was a company doing that, which costs money you understandand when I saw that track [Anna shows with her hands a length of half a meter] with those tiny footprints, then I simply... That simply exceeded my patience. Luckily, they had done only half of the track. If I had not gone there and stopped them, they would have stuck those tiny footprints over a few hundred meters of the hall. [Laugh] That was ridiculous. That was another group of people, so it kind of shows... The example with extinguishers was in one department, and the 'footprints' thing was in a completely different department, so the people did not work together, and they could not know about that silly case with the extinguishers. Those were completely independent teams, independent groups of people, but they thought the same way.

Already at the beginning of the story, Anna mentioned she was 'put off guard', which was predictive of some critical incident, a misfortune that would occur later in the story. Given her previous collaboration and cultural learning (cf., 'that was some time after the “extinguishers" thing'), the listener could anticipate the protagonist was going to make a similar mistake or fail to apply the knowledge acquired during the first unsuccessful collaboration. Indeed, it turned out that the photo given to the local colleagues was interpreted by them as a precise template for the track, which meant that all proportions needed to be respected.

Anna constructed herself as a heroine who intervened in the situation and stopped it before it would become worse from an economic point of view. In addition, again, the turning point anticipated at the beginning of this story was accompanied by negative affective states (anger) followed by cultural learning-Anna interrelated her previous and present collaboration experiences and realized that the failures could not be coincidental, as the two situations involved different teams of employees. Accordingly, 
she generalized about locals and narrated a story of local employees who interpreted instructions literally — which, however, implies that her instructions were not clear enough. Interestingly, although Anna's learning in Act II was fraught with negative emotions, the manner of relating the story was more humoristic than in the case of Act I. Her way of telling the story indicated her changing attitude to the subsequent collaboration failures.

\subsubsection{Act III. 'Meeting rooms'-Anna is 'back on guard'}

The following episode is about building 'meeting rooms' in the production hall for teams of operators:

I showed [the locals] those pictures first, but I was not caught off guard this time, I was not lulled, so I told them not to do anything their own way, based on those pictures, only because they seemed to think that it should be that way, and should not mess up, because this time it a lot of money was involved... So, they got detailed specifications to the nearest centimeter, to every detail, to the precise quality of the materials. And they did exactly what we had [in the home subsidiary], and the fit... it almost fit [laugh]. Because it turned out that they built the rooms according to the specifications, but they had not anticipated one thing... that these rooms would later have to be equipped with the right equipment. And what happened? It turned out that the door was too small [laugh]. The specifications we had [in the home subsidiary] were ideally suited to our equipment, and there [in the host subsidiary], the equipment was a bit bigger, so we simply took out the windows and equipped the rooms. But that was pretty hilarious, you know? [laugh]

Having learned from her previous experience with introducing new methods and solutions, Anna asked a construction office in her home subsidiary for the complete technical documentation for the 'meeting rooms'. In this way, she prepared the instructions in great detail to avoid ambiguity. In doing so, Anna showed a change in behavior to enhance her collaboration with the host nationals. Although some aspects were not anticipated (the size of the equipment), Anna finally perceived her collaboration as effective. Interestingly, this 'success' story, with Anna as a protagonist meeting her colleagues' expectations and furthering their collaboration, also contains a turning point, 'a fly in the ointment' — difficulties related to equipping the 'meeting rooms'. Nevertheless, Anna's positive emotions indicate that the problem was not too 
serious; she even found it humorous to remember the scene of taking the windows out to make room for the equipment (cf., 'that was pretty hilarious').

\subsection{Story II: 'Soaking in hot springs'-A lesson about respect}

In the next story, Anna told us about a three-day trip to hot springs with a multinational management team. The core theme was host country team members' unwillingness to bathe and socialize with a group of expats.

These [local] directors [managers] were already trained, so we were at the same hierarchical level, plus our [female] boss as leader-and she was soaking with us in these hot springs. And all five of us, I, a Frenchman, an American, a Mexican, and one [local manager], were soaking in there... while the others stayed in their rooms. It somehow showed this difference... it was very weird to me because they could have asked us to join them in their rooms. So, we were surprised and felt somehow inappropriate, uncomfortable. We did not like that... I did not like that at all, as I had just started having fun. It was evening... away from home, you can relax and spend your time differently. But here... I asked the [local manager] who was soaking with us why they all stayed in their rooms, and he said, 'I do not know. That is just the way it is'.

Anna emphasized the same hierarchical level of the locals and most of the expatriates (only the Western CEO was of higher status). Additionally, she legitimized the full membership of the local managers in the team by mentioning their professional training. However, despite that membership, Anna perceived the locals as alienated and unwilling to integrate with expatriates, which aroused negative feelings of embarrassment and discomfort in her.

Anna asserted that she tried to ask explicitly about the reasons for the host nationals' behavior from a host-country representative in order to learn from that critical incident, but he appeared to be unwilling to explain that to her, perhaps because he believed that the locals had already communicated their message. This subtle, nonverbal message had not been received and clearly understood by a person who had been socialized in a more direct and explicit communication style (Nardon, Steers, \& Sanchez-Runde, 2011). Failing to gain tacit cultural knowledge from her local colleague, she tried to rationalize that attitude by relating another situation she experienced after her return to her home subsidiary, when she received a delegation from the host subsidiary. 
I will tell you about an interesting situation so that you can understand their [local managers'] mentality. It explains why they did not come and join us in those hot springs. After coming back home [to the home country], a few months later, my boss [from the host country] brought her management team, those 25 people [to Anna's home country]. [In the host country] I had made close friends with one local manager from our team, and I said to him, 'Listen, because it is your first time here, I am inviting you to my house so that you can see how we live here'. And he says, 'Great! It will be a pleasure, but I do not want any dinner, I do not want to bother you'. So, we agreed that we would go out for dinner after visiting my house because I was very busy at the time hosting the delegation.

But I also knew one more [local] manager from the same team whom I liked very much as well. And I said to him, and he was... [Anna clears her throat] a subordinate to that first friend, 'Would you like to come to my house to see how I live here?' And he says, 'Sure, Anna, of course I would!' And I say, 'Cool. Liam will be coming together with us because I invited him, too'. And he says, 'Oh, so he is going to be there... Ok, I am not going then... It is not right [not desirable] that I go there with my boss'. And you know what? That gave me pause for thought later. I guess they didn't want to join us in those hot springs because they felt a bit... they treated us, expats, in a bit of a special way... as a bit higher level. That was totally unnecessary, as they were great people, but I think it may have been caused by some kind of respect. Because they didn't want to be in the same place with us after work, they simply didn't come down later to soak in the hot springs with us. Yes, that's how I would explain it.

The fragment begins with a turning point that allowed Anna to explain the local managers' behavior during the team-building exercise. The turning point was triggered by Anna's another cultural encounter with two local managers from the same team. Anna described her relations with them as friendly and sincere, so she invited them to her house. Although both managers eagerly accepted the invitation, one of them felt obliged to withdraw once he had learned that his higher-ranking colleague would also be visiting. The prosodic pause (signaled by the narrator clearing her throat) that preceded the information about the superior-subordinate relation between the two managers introduced a moment of deep reflection. It represents anagnorisis, a change from ignorance to knowledge, as Anna eventually recognized the meaning of hierarchy to the local managers and its role in regulating and maintaining interpersonal relations in both work and non-work contexts. Anna learned that the local managers' behavior, 
which she had initially interpreted as an unwillingness to socialize, may have been a cultural norm - a culture-based obligation to show respect to the expatriates' higher status in the hierarchy.

\subsection{Story III: 'Abuse of quasi-power'-Anna positions herself between expatriates and local employees}

In the following story, Anna is narrating a conflict driven by power struggles in which expatriates abuse their power vis-à-vis local employees:

There were frustrating situations, too, resulting from contacts with other expats. The locals were very diligent and obedient, and they did what they were instructed to. The most frustrating thing for me was when other expats tried to use their power against them. I strongly opposed that because it really affected me, you know? And such situations were common.

For example, we are at a meeting. There are locals, there is me, some American... and that group was very diverse with regard to managerial levels. And there turns out to be some quality problem in the production, and there is a [European manager] who is a quality control expert who, hmm... decided to show his 'expertise' [sarcasm]... in front of the others. So, he put a [local] girl in the middle of the room and started to literally ride roughshod over her, yelling that she had neglected some part of her job and had not controlled something, which resulted in the quality problem. So, he kind of accused her of that and shifted the whole responsibility completely onto her. Additionally, he started telling her off in front of everybody in the room and to tell her how she should behave. This situation was truly... drastic. And that girl... she burst into tears and... she kept standing there listening to his yelling. After that meeting, I met her in the restroom and saw her crying for a long time. So, there were situations when these expats heavily rode roughshod over the locals, really heavily, right? They were using their... quasi-power, hmm, to vent their... psychopathic? ... personality traits.

Whenever I saw something like that... I reacted during that meeting and pacified... I tried to cool that guy out and said we could handle it another way. And thanks to that, we finished the meeting earlier and he stopped scolding the girl. Nevertheless, after the meeting, he came to me and told me he did not wish to have me, in front of the locals, reprimand him. So, I said we could solve that problem in the boss' office then because he seemed not to understand what his role was. And indeed, we ended up in the boss' office. 
This dramatic and emotional story showed the narrator's construction of the scene as a public show involving a local female employee who was scolded, a male expatriate who was threatening her, and other expatriates and perhaps also local employees who were observing the scene. There was a problem that triggered a conflict and its resolutionpublic judgment of the 'suspect', finding her 'guilty', and giving her instructions in front of the others, which clearly appeared to be an act of humiliation or 'punishment'. For Anna, the conflict was caused by an expatriate who wanted to 'show off' in front of the other expatriates and perhaps 'teach' local employees a lesson and show them their place and who had the power.

Positioning herself in expatriate-local employee relationships was not an obvious choice for Anna in this specific situation. In the event of a conflict, she took the side of the local employee, even if she, like the other expatriates, could have remained passive and avoided engaging in the conflict and endangering her relationships with the other expatriates on the team. Anna construed three types of characters in the story: (1) a European expatriate who plays the role of the villain (having 'quasi-expertise', 'quasipower', etc.), (2) a local employee who acts as the victim ('crying', 'all responsibility shifted onto her'), and (3) Anna as a heroine who saves the victim and punishes or threatens the villain (she 'reacted', 'strongly opposed', etc.) and deconstructs his power position. Essentially, Anna recognized the expatriates' behaviors as morally wrong, as they aroused strong feelings of frustration. As a result, she showed empathy to the local employee whom, in turn, she conceived of as decent ('diligent', 'obedient'). She also ascribed the most frustrating situations to expatriates. Talking about 'quasi-power', Anna suggested that some expatriates had (or believed they had) substantial power over the local employees and thus placed themselves in a more favorable position. According to the story, e.g., the European manager distanced himself from the non-expatriates by implying that being reprimanded in front of the locals was a face-threatening act that undermined his authority and power position. However, he did the same to the local female employee, thereby expressing his power not only as an expatriate manager but also as a man.

\section{Discussion}

Anna, the European manager, presented herself as a well-educated and experienced individual with an international business profile. Working in the Western MNC for 15 
years allowed her to learn the MNC's corporate culture well. Moreover, Anna was also well-accustomed to working in a hierarchical organizational structure (typical of her home subsidiary), which should have translated into her better understanding the Asian paternalistic leadership style where hierarchy, benevolence, and the rule of morality are emphasized (Chen \& Lee, 2008; Steers, Sanchez-Runde, \& Nardon, 2012). However, our analyses showed that a highly multicultural business context posed a serious challenge to Anna, whose function of a boundary spanner entailed working with a multinational group of people at different managerial levels. Prior international experience in other countries turned out to be insufficient to ensure smooth crosscultural interactions in the host country, which confirms that 'each foreign assignment is a cumulative learning experience that provides expatriates with a broadened international perspective and a range of mechanisms to cope with complexity and diversity' (Hocking et al., 2007, p. 529). The new multicultural business setting required capturing new context-specific knowledge that would help Anna discern what behaviors worked best in that setting, which — as her stories showed-was oftentimes fraught with failures.

In the following sections, we discuss the research questions in light of the findings.

\subsection{How did the European expatriate manager retrospectively interpret and emplot} her collaboration encounters with Asian employees and managers and what did her stories reveal about her cultural learning?

Our narrative analysis highlighted culture-specific issues in Anna's collaborations with local employees and managers, such as her perceptions of different power relations or different understandings of hierarchy, which she found challenging when implementing the headquarters' standardization procedures. For example, Anna recounted that her trainees could not break through the 'hierarchical barrier' and persuade their local superiors to introduce new production methods. Her perception of hierarchical relations in the new business and socio-cultural context suggests that she evaluated the observed behaviors of locals based on her own cultural socialization in her home subsidiary. In turn, her expectation that local managers would easily adopt the headquarters' standardization procedures may reflect the effect of the MNC's ethnocentric management approach on diverting expatriates' attention from 'the needs of crosscultural sensitivity learning' (Wong, 2001, p. 248). Finally, her view of the local 
subordinates as rather passive and showing little initiative, and not adapting her instructions to the local context, suggests that she believed the locals should have conformed to her own cultural expectations (Turner, 2006) which differed from what they found appropriate in their cultural context.

The analyses showed that the early stage of Anna's functioning in the new context was marked by limited cultural learning, even though she had acquired explicit cultural knowledge about the host country from various sources of information (books, the Internet, other expats, her host language teacher, cross-cultural training, etc.). Thus, we found that studying as an intercultural learning process was insufficient for discerning the perspective of the cultural other, which is in line with prior research showing the strategic importance of generic, yet company-specific (tacit) knowledge embedded in the local organizational culture, practices, and routines (Hocking et al., 2007).

Anna's first three-act story demonstrated her conditioning, a trial-and-error learning process that was fraught with failure. Having no prior experience with the host culture, she gradually learned to be effective in the new socio-cultural context through collaborations with locals. This finding confirms high effectiveness of observation and conditioning for expatriate individual learning (Hocking et al., 2007). Anna learned that in order to avoid communication ambiguity, she needed to communicate explicitly and provide precise instructions. She seems to have embedded this necessity into her own understanding of how hierarchy worked in an Eastern business setting and linked the need for direct instructions with the concept of trust, i.e., what subordinates are given by their superior must be appropriate. This explicit sense making of local relationships and employees' motivations exemplifies attributional reasoning. Accordingly, we established a link between implicit learning (conditioning) and explicit learning (attributional reasoning), as her story suggested that the process of adjusting behaviors to a given situation was accompanied by extrapolating from other social situations.

Anna's first story showed her emotional reactions to unsuccessful collaborations. At times, she felt shocked, guilty, surprised, or angry, but the more successful she was in her collaborations with the locals, the more positive emotions that work aroused. This indicates that emotions play a role in effective conditioning — while negative emotions may trigger a change in behaviors, positive emotions aroused during storytelling may potentially reinforce the learning process and the knowledge produced as a result of it. Our analyses showed that Anna's cultural learning (a) was accompanied 
by affective states, which is in line with prior research (Gertsen \& Søderberg, 2011), (b) was followed by sense making of collaborations with different teams of local employees but also (c) occurred in retrospect after her return home. Those properties indicate that Anna's learning was both implicit (as implicit knowledge is based on emotions) and explicit (as sense making involves reflection).

The second story also showed Anna's attributional reasoning, but this time it occurred after her return to Europe. Anna revised her initial perception of the local managers' behavior during a team-building trip as alienating when she invited two local colleagues to visit her house. Learning about their specific superior-subordinate relations gave her grounds for reflection on her previous intercultural experience, which she initially could not understand and which resulted in her discomfort; presumably, she misinterpreted the local managers' behavior in the hot springs and was unable to learn about their motivations from a host-country representative whom she openly asked to explain the message sent to her and the other expatriates through that non-verbal communication. Later, she learned about the local understanding of hierarchy as applied in work and non-work contexts both in the host and home country. She realized that the locals' behavior she had interpreted a few months before as 'alienation' may have been a subtle manifestation of a respectful attitude toward the CEO and the other expatriate managers by 'honoring prescribed power-based membership identities' (Taylor \& Osland, 2011, p. 589). Given this, we found that although attributional reasoning leads to learning through extrapolation from social interactions, it may well lead to misinterpretations of cultural others' behaviors and, as a result, inhibit social interactions with them (e.g., when cultural others are misperceived as 'alienated'). We also found that further intercultural interactions serve as a tool for recalibrating previous attributions and that cultural learning does not have to occur overnight, as it may well be triggered by relating events and intercultural experiences. This finding shows that the explicit cultural knowledge created through attributional reasoning does not ensure such learning that allows one to transcend his/her own perspective, but it needs to be constantly renegotiated in social interaction.

Finally, the dramatic story of an expatriate abusing his power vis-à-vis a local employee shows that Anna learned about her expatriate colleagues through observation, which is typical of attributional reasoning. This story exemplifies what narrative literature recognizes as one of 'unique selling points of stories', i.e., their ethical dimension (Greenhalgh, Russell, \& Swinglehurst, 2005), because it reflects the society's 
expectation about how a 'righteous' person should have behaved in a situation of oppression. Thus, this story unfolded as a personal 'variant of the culture's canonical form' (Bruner, 2004) on which Anna drew to express her empathy for the local female employee who had publicly been reprimanded by another expatriate manager. The story shed light on the dark side of a multicultural workplace, as it depicted it as a stage of power struggles at the expatriate-local personnel level, at the between-expatriate level, and in a gendered setting.

With our narrative study, we supported other scholars' assumption that emotionally powerful experiences have transformative potential for learning (Bird, 2014; Søderberg, 2017). Recounting them in the storytelling process triggers an expatriate's post-experiential reinterpretation of his/her perceptions of intercultural interactions.

\subsection{How did the expatriate position herself in her stories in relation to local personnel and other expatriates?}

Story I suggests that Anna addressed the 'dual allegiance dilemma' (Fitzsimmons, Miska, \& Stahl, 2011) by playing the role of liaison between the headquarters, her home (European) subsidiary, and host (Eastern) subsidiary. When transferring knowledge between the two subsidiaries, she seems to have exhibited a 'dual citizen' attitude (Fitzsimmons et al., 2011) by trying to reconcile headquarters' expectations of implementing globally consistent production methods and, at the same time, showing respect and understanding of the local hierarchical structure and power relations and trying to function in that socio-cultural context by learning how to effectively communicate with local managers and employees. In other words, Anna participated in creating a hybrid organizational culture by melding corporate goals with local expectations (Shim \& Steers, 2012).

Anna often ascribed difficulties in introducing new methods to her local trainees who lacked power. By contrast, she perceived local managers as acting independently and being resistant to her subordinates' suggestions, and through that juxtaposition, she was able to make sense of the strong power relations at the workplace (Pinto \& Caldas, 2015). The unequal distribution of power was accepted (House, Hanges, Javidan, Dorfman, \& Gupta, 2004) by the local subordinates who easily succumbed to their local managers. Anna created a narrative of high-level managers and low-level employees and fitted herself somewhere in between them by construing her own role as an expert, 
intermediary, coach, and teacher whose job was to direct lower-level employees and introduce solutions that previously worked in her home subsidiary.

Little prior experience with the host nationals and little knowledge of the local environment would suggest that Anna, as a newcomer, would tend to act ethnocentrically in her collaborations with local personnel (Gertsen \& Søderberg, 2011). Although it took some time until she learned about what she generalized as the '[local managers'] mentality', she appears to have drawn on her international experiences from other sites to position herself in a highly multicultural environment in the host subsidiary, e.g., in conflict situations driven by power struggles between expatriates and local employees. For instance, in Story III, face-threatening behavior (scolding in public) by another expatriate forced Anna to take a position in an expatriate-local employee conflict and reflect on her role in the venture she was part of. In narrative terms, she positioned herself as a heroine who defended a local female employee against a male expatriate. It must be noted, however, that although this positive self-portrayal could not be vetted through a relation of any other organizational actor participating in the event, opposing another European manager in the setting dominated by expatriates must have required some courage. By reacting to the unacceptable behavior, she exhibited ethical universalism and ensured that the expatriates' activities were ethically sound (Gertsen \& Søderberg, 2010). Thus, she extended the image of an expatriate by highlighting the role of maintaining fair and ethical relations in the local subsidiary for the benefit of both expatriate-local personnel and between-expatriate relations; in the long run, the outcome of playing this role could lead to strengthened headquarters-local subsidiary relations and improve the image of an expatriate who may otherwise be perceived by local personnel as an opponent, controller or oppressor rather than a partner.

We also found that a self-critical reflection of cross-cultural collaboration helped Anna gradually develop an open attitude toward the locals. She related her collaboration failures to her own strategy of delegating responsibility to her subordinates and treated her local colleagues as peers despite their different positions in the company hierarchy. As shown in the stories, her efforts to change her behaviors translated into her professional development and led to more successful collaborations.

Despite all the failures, Anna had a positive outlook on her collaborations. The development of this perspective started with her somewhat patronizing attitude toward her '[local] girls' and proceeded through identifying with and defending a local 
employee (although she was responsible for serious failures) to form her final perspective on some local managers as peers and collaborators (initially perceived as 'resistant' and 'working independently') whom she invited to visit her home.

\subsection{What was the impact of the exercise of storytelling on the expatriate's learning after repatriation?}

Our findings suggest that the narrative research method positively enhanced the European expatriate manager's reflexivity and allowed her to develop new understandings of her intercultural experiences. Having been presented with a draft of this paper, she told us that it gave her a chance to reflect further on her cross-cultural collaboration in the host subsidiary and deepened her understanding of its culturespecific aspects (e.g., communication and superior-subordinate relations), the locals' behaviors, and her roles played as an expatriate manager. By taking part in the narrative interview, Anna could reinforce the effects of her cultural learning, which she could later diffuse in the European subsidiary of the MNC (Lazarova \& Tarique, 2005) by coproducing the explicit knowledge presented herein.

We identify a notable methodological contribution of this narrative study. Although narrative interviews allowed us to collect rich and personal stories, they also unfolded as vehicles of a mono-dimensional perspective on cross-cultural encounters. It turned out that the procedure of conducting a narrative interview, which is aimed at capturing the personal perspective on the interviewee's experiences (Jovchelovitch \& Bauer, 2000), may actually invite an ethnocentric perspective and prevent the interviewee from transcending this perspective. Therefore, the task of telling stories to the interviewer who shared a nationality, language, and culture with Anna may have imposed a home-culture's lens on her own and cultural others' behaviors. This finding is evidenced in her explicit motivations for relating some stories, such as 'I will tell you about an interesting situation so that you can understand their [local managers'] mentality'. We assume that she may have found the interviewer to be expecting her to tell stories of cross-cultural differences, which in turn affected her selection of stories that would allow building a narrative of significantly different national mentalities, different ways of thinking, and different cultural norms. In other words, we found that the specific interviewer-interviewee relation influenced the co-production of narratives to such an extent that, first, it directed the interviewee to select stories that would satisfy the interviewer. Second, the specific interview context limited the interviewee's ability 
to transcend her home-culture perspective and take a more empathetic approach to locals' behaviors.

\section{Limitations and avenues for future research}

Our findings should be viewed in light of the study's limitations that point out future directions for research. The findings are based on stories told by one manager only; it was not designed to provide generalizations, but to provide a thick description and an in-depth analysis of the stories told and provoke interest in expatriates' cultural learning through narrative inquiry. Nevertheless, in future research, more plurivocality can be gained by interviewing local organizational actors, too. Their accounts may provide additional perspectives on the same critical events and the retrospective interpretations of them.

The expatriate manager's collaboration stories exemplify (micro)narratives of learning about cultural others and their behaviors as well as about the narrator's own identity, roles, and reactions to those behaviors in new contexts. We suggest that such (micro)narratives should be further studied to provide subjective, rich descriptions of interactive business phenomena (Ivanova-Gongne \& Törnroos, 2017; Makkonen, Aarikka-Stenroos, \& Olkkonen, 2012) in order to gain deeper insights into the ongoing sense making of intercultural experiences.

Future research could also develop the basic conditions for the occurrence of 'trigger events'; i.e., occasions that allow people to notice cultural differences and make sense of intercultural interactions (Osland, Bird, \& Gundersen, 2008). In addition to the obvious advantages of studying trigger events in naturalistic settings (Osland et al., 2008), studying organizational actors' narratives could deepen our understanding of how the actual events that lead to cultural learning are emplotted and perceived by various actors and what learning processes they trigger.

Nevertheless, researchers should pay special attention to the context of eliciting stories and plan data collection procedure in a way that would reduce the possibility of - unintendedly - imposing an ethnocentric perspective of the past events on the storyteller, e.g., by conducting interviews in the interviewee's language. Although using the interviewee's mother tongue allows eliciting the interviewee's emotionally laden perspective on a specific course of events with more nuances (e.g., Jovchelovitch \& Bauer, 2000; Marschan-Piekkari \& Reis, 2004), our study showed that such perspective 
may at the same time limit the self-reflection of communication processes in crosscultural contexts. Similarly to prior methodological solutions, e.g., for overcoming the problem of withdrawing much information caused by social identity, power, and the interviewee's position by replacing "the interviewer by one whose social status is deemed more appropriate in terms of gender, ethno-cultural background or other salient aspects of identity" (Groleau, Young, \& Kirmayer, 2006, p. 680), a way to minimize the risk of imposing an ethnocentric perspective could be collecting stories in a second language by an interviewer who does not share cultural background with the interviewee). Thus, future (narrative) research into such a perspective-sensitive phenomenon as learning in cross-cultural contexts could use stories elicited by interviewers with different cultural backgrounds from the interviewee.

\section{Conclusion}

In this paper, combining narrative inquiry and a 'four-fold taxonomy of intercultural learning processes' (Morris et al., 2014), we examined how a European female manager emplotted her intercultural encounters in an Eastern/Asian subsidiary of a Western MNC, how she made sense of and gave sense to the critical collaboration processes, and how she positioned herself in relation to culturally diverse others. We also showed how and what she learned from her experiences to be successful in multicultural business settings. Accordingly, we developed a relationship between experience, narrative (as a sense making and sense giving tool), cultural identity, and learning processes.

We showed that narrative inquiry is well suited to elucidating cultural learning in cross-cultural collaborations (Gertsen \& Søderberg, 2011, 2010). By identifying turning points (peripeteia) and the narrator's discoveries and recognition (anagnorisis) in the stories, we managed to identify conditioning processes and attributional reasoning processes that constitute both implicit and explicit learning, respectively. We suggest that narrative inquiry is best suited for studying these two learning processes, which are essentially anchored in learning by practice and in sense making, as narrative inquiry focuses on narratives in which a narrator, among other things, (a) relates events about unique causal relations and contexts (Gabriel, 2000), (b) ascribes specific features, levels of importance, and evaluations to events and actors (Søderberg \& Worm, 2011), and (c) constructs his/her own and others' identities in a sense-making process (Weick, 1995). 
Moreover, we suggest that narrative interviewing could be used not only by researchers, but also by mentors in an MNC as a method to stimulate expatriates' reflection on their cross-cultural interactions and understanding of the other. It could show where collaboration can be improved, trust can be built, and intercultural communication competence and cultural intelligence developed (Søderberg, 2017). Such investigations can later be translated into cross-cultural education programs where managers are offered training sessions, including reflections on examples of actual experiences of critical encounters, and thereby raise their cultural metacognition to further creative collaborations (Chua, Morris, \& Mor, 2012; Osman-Gani \& Rockstuhl, 2008) in multicultural business settings.

By giving voice to this European expatriate manager's perspective on communication and collaborations with Eastern personnel, we contribute to a research field where the voices of individuals are seldom listened to. We managed to obtain personal and emotionally laden stories in which individual intercultural experiences are uniquely emplotted and linked the rational aspects of an organizational change process with encounters between organizational actors and their feelings (Soin \& Scheytt, 2006). Moreover, given the limitations of the procedure of narrative interview described above, we hope that with this study we were able to offer methodological solutions to promote future research that will develop the potential of narrative method to advance our knowledge of cross-cultural communication and learning processes.

We also contribute to the literature on expatriate managers' cultural learning by showing the relevance of the 'taxonomy of intercultural learning processes' as a useful sensitizing framework to establish and gain insight into qualitatively different but interrelated processes of expatriate cultural learning based on challenging situations of cross-cultural collaborations. Because the framework allows recognizing the social dimension of cultural learning, we could present the manager's learning processes that took place before, during, and long after expatriation as a result of cultural encounters, but also as a result of acquiring explicit knowledge and reproducing it in social interactions with host country nationals, other expatriates, and the interviewer.

\section{Acknowledgements}

This work was supported by the 'Mobility Plus' program of the (Polish) Ministry of Science and Higher Education under Grant [1310/MOB/IV/2015/0] to Michał Wilczewski; Department of Management, Society and Communication, Copenhagen 
Business School to Anne-Marie Søderberg; The National Science Centre (Poland) under Harmonia 6 Grant [UMO-2014/14/M/HS1/00436] to Arkadiusz Gut. We are grateful to the interviewee who willingly contributed to this study and to three reviewers for their insightful comments.

\section{Bibliography}

Abbe, A., Gulick, L. M. V, \& Herman, J. L. (2008). Cross-cultural competence in army leaders: A conceptual and empirical foundation. Arlington, VA.

Ang, S., \& Van Dyne, L. (2008). Conceptualization of cultural intelligence: Definition, distinctiveness, and nomological network. In S. Ang \& L. Van Dyne (Eds.), Handbook on cultural intelligence: Theory, measurement and applications (pp. 313). Armonk, NY: M.E. Sharpe.

Ang, S., Van Dyne, L., Koh, C., Ng, K. Y., Templer, K. J., Tay, C., \& Chandrasekar, N. A. (2007). Cultural intelligence: Its measurement and effects on cultural judgment and decision making, cultural adaptation and task performance. Management and Organization Review, 3(3), 335-371. https://doi.org/10.1111/j.17408784.2007.00082.x

Armstrong, S. J., \& Li, Y. (2017). A study of Anglo expatriate managers' learning, knowledge acquisition, and adjustment in multinational companies in China. Academy of Management Learning and Education, 16(1), 1-22. https://doi.org/10.5465/amle.2013.0335

Bandura, A. (1977). Social learning theory. Englewood Cliffs, NJ: Prentice Hall. Bandura, A. (1986). Social foundations of thought and action: A social cognitive theory. Prentice Hall series in social learning theory (Vol. 1). Englewood Cliffs, NJ: Prentice Hall.

Bauer, M. W., \& Gaskell, G. (2000). Individual and group interviewing. In M. W. Bauer \& G. Gaskell (Eds.), Qualitative researching with text, image and sound: A practical handbookfor social research (pp. 38-56). London: Sage Publications. https://doi.org/10.4135/9781849209731.n4

Bird, A. (2014). Introduction: Experiencing the world. In V. Taras \& M.-A. GonzalezPerez (Eds.), The Palgrave handbook of experiential learning in international business (pp. 3-11). New York, NY: Palgrave Macmillan.

Bird, A., \& Mendenhall, M. E. (2016). From cross-cultural management to global leadership: Evolution and adaptation. Journal of World Business, 51(1), 115-126. 
https://doi.org/10.1016/j.jwb.2015.10.005

Black, J. S., \& Mendenhall, M. (1991). The U-Curve adjustment hypothesis revisited: A review and theoretical framework. Journal of International Business Studies, 22(2), 225-247. https://doi.org/10.1057/palgrave.jibs.8490301

Brannen, M. Y., \& Salk, J. E. (2000). Partnering across borders: Negotiating organizational culture in a German-Japanese joint venture. Human Relations, 53(4), 451-487. https://doi.org/10.1177/0018726700534001

Bruner, J. (2004). Life as narrative. Social Research, 71(1), 691-711. https://doi.org/10.1007/s10780-008-9039-2

Caligiuri, P. M. (2000a). Selecting expatriates for personality characteristics: A moderating effect of personality on the relationship between host national contact and cross-cultural adjustment. Management International Review, 40(1), 61-80. https://doi.org/10.2307/40835867

Caligiuri, P. M. (2000b). The Big Five personality characteristics as predictors of expatriate's desire to terminate the assignment and supervisor-rated performance. Personnel Psychology, 53(1), 67-88. https://doi.org/10.1111/j.17446570.2000.tb00194.x

Caligiuri, P. M., \& Tarique, I. (2012). Dynamic cross-cultural competencies and global leadership effectiveness. Journal of World Business, 47(4), 612-622. https://doi.org/10.1016/j.jwb.2012.01.014

Chen, C.-C., \& Lee, Y.-T. (Eds.). (2008). Leadership and management in China: Philosophies, theories, and practices. New York, NY: Cambridge University Press.

Chua, R. Y. J., Morris, M. W., \& Mor, S. (2012). Collaborating across cultures: Cultural metacognition and affect-based trust in creative collaboration. Organizational Behavior and Human Decision Processes, 118(2), 116-131. https://doi.org/10.1016/j.obhdp.2012.03.009

Daiute, C., \& Lightfoot, C. (Eds.). (2004). Narrative analysis: Studying the development of individuals in society. Thousand Oaks, CA: Sage Publications.

Dalton, M., \& Wilson, M. (2000). The relationship of the five-factor model of personality to job performance for a group of Middle Eastern expatriate managers. Journal of Cross-Cultural Psychology, 31(2), 250-258. https://doi.org/10.1177/0022022100031002007

Damşa, C. I., \& Ludvigsen, S. (2016). Learning through interaction and co-construction 
of knowledge objects in teacher education. Learning, Culture and Social Interaction, 11, 1-18. https://doi.org/10.1016/j.lcsi.2016.03.001

Davis, T. R. V., \& Luthans, F. (1980). A social learning approach to organizational behavior. Academy of Management Review, 5(2), 281-290. https://doi.org/10.2307/257438

Deardorff, D. K. (2006). Identification and assessment of intercultural competence as a student outcome of internationalization. Journal of Studies in International Education, 10(3), 241-266. https://doi.org/10.1177/1028315306287002

Farh, J.-L., \& Cheng, B.-S. (2000). A cultural analysis of paternalistic leadership in Chinese organizations. In J. T. Li, A. S. Tsui, \& E. Weldon (Eds.), Management and organizations in the Chinese context (pp. 84-127). London: Macmillan. https://doi.org/10.1057/9780230511590_5

Fitzsimmons, S. R., Miska, C., \& Stahl, G. K. (2011). Multicultural employees: Global business' untapped resource. Organizational Dynamics, 40(3), 199-206. https://doi.org/10.1016/j.orgdyn.2011.04.007

Fleming, D. (2001). Narrative leadership: using the power of stories. Strategy \& Leadership, 29(4), 34. https://doi.org/10.1108/s1.2001.26129dab.002

Fowler, S. M., \& Blohm, J. M. (2004). An analysis of methods for intercultural training. In D. Landis, J. M. Bennett, \& M. J. Bennett (Eds.), Handbook of intercultural training (3rd ed., pp. 37-84). Thousand Oaks, CA: Sage. https://doi.org/10.4135/9781452231129.n3

Freeman, M. (2004). Data are everywhere: Narrative criticism in the literature of experience. In C. Daiute \& C. Lightfoot (Eds.), Narrative analysis: Studying the development of individuals in society (pp. 63-82). Thousand Oaks, CA: Sage. https://doi.org/http://dx.doi.org/10.4135/9781412985246

Gabriel, Y. (2000). Storytelling in organizations: Facts, fictions, and fantasies. Oxford: Oxford University Press.

Gabriel, Y. (2004). Narratives, stories and texts. In D. Grant, C. Hardy, C. Oswick, \& L. L. Putnam (Eds.), The SAGE handbook of organizational discourse (pp. 61-78). London: Sage Publications. https://doi.org/10.4135/9781848608122.n3

Galasiński, D., \& Galasiska, A. (2005). Untold stories and the construction of identity in narratives of ethnic conflict on the Polish-German border. Multilingua, 24(1-2), 101-120. https://doi.org/10.1515/mult.24.1-2.101

Gertsen, M. C., \& Søderberg, A.-M. (2011). Intercultural collaboration stories: On 
narrative inquiry and analysis as tools for research in international business.

Journal of International Business Studies, 42(6), 787-804.

https://doi.org/10.1057/jibs.2011.15

Gertsen, M. C., \& Søderberg, A. M. (2010). Expatriate stories about cultural encounters: A narrative approach to cultural learning processes in multinational companies.

Scandinavian Journal of Management, 26(3), 248-257.

https://doi.org/10.1016/j.scaman.2010.06.003

Gioia, D. A., \& Chittipeddi, K. (1991). Sensemaking and sensegiving in strategic change initiation. Strategic Management Journal, 12(6), 433-448. https://doi.org/10.1002/smj.4250120604

Greenhalgh, T., Russell, J., \& Swinglehurst, D. (2005). Narrative methods in quality improvement research. Quality and Safety in Health Care. https://doi.org/10.1136/qshc.2005.014712

Groleau, D., Young, A., \& Kirmayer, L. J. (2006). The McGill Illness Narrative Interview (MINI): An Interview schedule to elicit meanings and modes of reasoning related to illness experience. Transcultural Psychiatry, 43(4), 671-691. https://doi.org/10.1177/1363461506070796

Hampden-Turner, C. M., \& Trompenaars, F. (2000). Building cross-cultural competence. How to create wealth from conflicting values. New Haven, CT: Yale University Press.

Hocking, J. B., Brown, M., \& Harzing, A.-W. (2007). Balancing global and local strategic contexts: Expatriate knowledge transfer, applications, and learning within a transnational organization. Human Resource Management, 46(4), 513-533. https://doi.org/10.1002/hrm.20180

House, R. J., Hanges, P. J., Javidan, M., Dorfman, P. W., \& Gupta, V. (2004). Culture, Leadership, and Organizations. The GLOBE Study of 62 Societies. Retrieved from http://books.google.de/books?id=_KsXEJQg9pkC\&dq=intitle:Culture+Leadership $+\mathrm{I}+$ Organizations $\& \mathrm{hl}=\& \mathrm{~cd}=1 \&$ source=gbs_api\%5Cnpapers2://publication/uuid/51 2B92AA-A29D-4E9F-9B45-59376DAF9E6F

Hsiung, P. C. (2008). Teaching reflexivity in qualitative interviewing. Teaching Sociology, 36(3), 211-226. https://doi.org/10.1177/0092055X0803600302

Hyvärinen, M. (2008). Analyzing narratives and Story-Telling. In P. Alasuutari, L. Bickman, \& J. Brannen (Eds.), The SAGE Handbook of Social Research Methods (pp. 447-460). Los Angeles, LA: Sage. https://doi.org/10.4135/9781446212165 
Ishihara, N., \& Menard-Warwick, J. (2018). In "sociocultural in-betweenness": Exploring teachers' translingual identity development through narratives. Multilingua: Journal of Cross-Cultural and Interlanguage Communication, 37(3), 255-274. https://doi.org/10.1515/multi-2016-0086

Ivanova-Gongne, M., \& Törnroos, J. Å. (2017). Understanding cultural sensemaking of business interaction: A research model. Scandinavian Journal of Management, 33(2), 102-112. https://doi.org/10.1016/j.scaman.2017.04.001

Janssens, M., Cappellen, T., \& Zanoni, P. (2006). Successful female expatriates as agents: Positioning oneself through gender, hierarchy, and culture. Journal of World Business, 41(2), 133-148. https://doi.org/10.1016/j.jwb.2006.01.001

Jovchelovitch, S., \& Bauer, M. W. (2000). Narrative interviewing. In M. W. Bauer \& G. D. Gaskell (Eds.), Qualitative researching with text, image and sound (pp. 58-75). London: Sage. https://doi.org/10.4135/9781849209731

Joy, S., \& Kolb, D. A. (2009). Are there cultural differences in learning style? International Journal of Intercultural Relations, 33(1), 69-85. https://doi.org/10.1016/j.ijintrel.2008.11.002

Kogut, B., \& Zander, U. (2003). Knowledge of the firm and the evolutionary theory of the multinational corporation. Journal of International Business Studies, 34(6), 516-529. https://doi.org/10.1057/palgrave.jibs.8400058

Koh, J. B. K., \& Wang, Q. (2013). Narrative self-making during dinnertime conversations in Chinese immigrant families. In A. McCabe \& C. Chang (Eds.), Chinese language narration: Culture, cognition, and emotion (Studies in Narrative, Vol. 19) (pp. 7-32). Amsterdam \& Philadelphia: John Benjamins.

Kolb, A. Y., \& Kolb, D. A. (2005). Learning styles and learning spaces: Enhancing experiential learning in higher education. Academy of Management Learning \& Education, 4(2), 193-212. Retrieved from http://www.jstor.org/stable/40214287\%5Cnhttp://www.jstor.org/stable/40214287? seq $=1 \&$ cid $=$ pdfreference\#references_tab_contents\%5Cnhttp://about.jstor.org/terms\%5Cnhttp://wi ki.biologyscholars.org/@api/deki/files/2212/=Learning_Styles_and_Learning_Spa ces__Enha

Kolb, D. A. (1984). Experiential learning: Experience as the source of learning and development. Englewood Cliffs, NJ: Prentice Hall.

Kolb, D. A., Boyatzis, R. E., \& Mainemelis, C. (2000). Experiential learning theory: 
Previous research and new directions. In R. J. Sternberg \& L.-F. Zhang (Eds.), Perspectives on thinking learning and cognitive styles (Vol. 1, pp. 227-247). New York, NY: Lawrence Erlbaum. https://doi.org/10.5465/AMLE.2005.17268566 Landis, D., \& Bhawuk, D. P. S. (2004). Synthesizing theory building and practice in inter-cultural training. In D. Landis, J. M. Bennet, \& M. J. Bennett (Eds.), Handbook of intercultural training (3rd ed., pp. 451-466). Thousand Oaks, CA: Sage. https://doi.org/10.4135/9781452231129.n19

Lazarova, M., \& Tarique, I. (2005). Knowledge transfer upon repatriation. Journal of World Business, 40(4), 361-373. https://doi.org/10.1016/j.jwb.2005.08.004

Lenartowicz, T., Johnson, J. P., \& Konopaske, R. (2014). The application of learning theories to improve cross-cultural training programs in MNCs. International Journal of Human Resource Management, 25(12), 1697-1719. https://doi.org/10.1080/09585192.2013.860384

Li, M., Mobley, W. H., \& Kelly, A. (2013). When do global leaders learn best to develop cultural intelligence? An investigation of the moderating role of experiential learning style. Academy of Management Learning and Education. https://doi.org/10.5465/amle.2011.0014

Makkonen, H., Aarikka-Stenroos, L., \& Olkkonen, R. (2012). Narrative approach in business network process research-Implications for theory and methodology. Industrial Marketing Management, 41(2), 287-299. https://doi.org/10.1016/j.indmarman.2012.01.012

Manuti, A., Pastore, S., Scardigno, A. F., Morciano, M. L., \& Giancaspro, D. (2015). Formal and informal learning in the workplace: A research review. International Journal of Training and Development, 19(1), 1-17. https://doi.org/10.1111/ijtd.12044

Marschan-Piekkari, R., \& Reis, C. (2004). Language and languages in cross-cultural interviewing. In R. Marschan-Piekkari \& C. Welch (Eds.), Handbook of qualitative research methods for international business (pp. 224-243). Cheltenham, UK: Edward Elgar Publishing.

Méndez García, M. del C. (2017). Intercultural reflection through the "Autobiography of Intercultural Encounters": Students' accounts of their images of alterity. Language and Intercultural Communication, 17(2), 90-117. https://doi.org/10.1080/14708477.2016.1159693

Mezirow, J. (1991). Transformative dimensions of adult learning. San Francisco, CA: 
Jossey-Bass.

Mol, S. T., Born, M. P., \& van der Molen, H. T. (2005). Developing criteria for expatriate effectiveness: Time to jump off the adjustment bandwagon. International Journal of Intercultural Relations. https://doi.org/10.1016/j.ijintrel.2005.05.004

Morris, M. W., Savani, K., Mor, S., \& Cho, J. (2014). When in Rome: Intercultural learning and implications for training. Research in Organizational Behavior, 34, 189-215. https://doi.org/10.1016/j.riob.2014.09.003

Nardon, L., Steers, R. M., \& Sanchez-Runde, C. J. (2011). Seeking common ground. Strategies for enhancing multicultural communication. Organizational Dynamics, 40(2), 85-95. https://doi.org/10.1016/j.orgdyn.2011.01.002

Nonaka, I. (1994). A dynamic theory of organizational knowledge creation. Organization Science, 5(1), 14-37. https://doi.org/10.1287/orsc.5.1.14

Osland, J. S., Bird, A., \& Gundersen, A. (2008). Trigger events in intercultural sensemaking. In Academy of International Business Meeting. Milan, Italy. Retrieved from http://www.umsl.edu/divisions/business/seminar_series/2009 Spring Seminar Series in Business and Economics ppt files/Trigger Events.doc

Osman-Gani, A. M., \& Rockstuhl, T. (2008). Consequences of Social Network Characteristics for Expatriate Adjustment \& Performance in Overseas Assignments: an Empirical Investigation of Managers in Asia. Academy of Management Annual Meeting Proceedings, 8(1), 1-6. https://doi.org/10.5465/AMBPP.2008.33633336

Pavlenko, A. (2007). Autobiographic narratives as data in applied linguistics. Applied Linguistics, 28(2), 163-188. https://doi.org/10.1093/applin/amm008

Piller, I. (2011). Intercultural communication: A critical introduction. Edinburgh: Edinburgh University Press.

Pinto, L. H., \& Caldas, R. (2015). Making sense of expatriation. Management Research: Journal of the Iberoamerican Academy of Management, 13(3), 267-284. https://doi.org/10.1108/MRJIAM-07-2014-0559

Plum, E., Achen, B., Dræby, I., \& Jensen, I. (2008). CI-Cultural intelligence-The art of leading cultural complexity. London: Middlesex University Press.

Polkinghorne, D. E. (1988). Narrative knowing and the human sciences. Albany, NY: State University of New York Press.

Porter, G., \& Tansky, J. W. (1999). Expatriate success may depend on a "learning 
orientation": Considerations for selection and training. Human Resource

Management, 38(1), 47-60. https://doi.org/10.1002/(SICI)1099-

050X(199921)38:1<47::AID-HRM5>3.0.CO;2-1

Saldaña, J. (2016). The coding manual for qualitative researchers. Los Angeles [etc.]: Sage Publications.

Selmer, J. (2001). Coping and adjustment of Western expatriate managers in Hong Kong. Scandinavian Journal of Management, 17(2), 167-185. https://doi.org/10.1016/S0956-5221(99)00040-8

Shaffer, M. A., Gregersen, H., Ferzandi, L. A., Harrison, D. A., \& Black, J. S. (2006). You can take it with you: Individual differences and expatriate effectiveness. Journal of Applied Psychology, 91(1), 109-125. https://doi.org/10.1037/00219010.91.1.109

Shim, I.-S., \& Paprock, K. E. (2002). A study focusing on American expatriates' learning in host countries. International Journal of Training and Development, 6(1), 13-24. https://doi.org/10.1111/1468-2419.00146

Shim, W. S., \& Steers, R. M. (2012). Symmetric and asymmetric leadership cultures: A comparative study of leadership and organizational culture at Hyundai and Toyota. Journal of World Business, 47(4), 581-591. https://doi.org/10.1016/j.jwb.2012.01.011

Søderberg, A.-M. (2006). Narrative interviewing and narrative analysis in a study of a cross-border merger. Management International Review, 46(4), 397-416. https://doi.org/10.1007/s11575-006-0098-2

Søderberg, A.-M. (2015). Recontextualising a strategic concept within a globalising company: A case study on Carlsberg's 'Winning Behaviours' strategy. International Journal of Human Resource Management, 26(2), 231-257. https://doi.org/10.1080/09585192.2014.922358

Søderberg, A.-M. (2017). Experience and cultural learning in global business contexts. In L. Chen (Ed.), Intercultural communication (pp. 415-435). Boston, MA \& Berlin: Mouton de Gruyter.

Søderberg, A.-M., \& Worm, V. D. (2011). Communication and collaboration in subsidiaries in China - Chinese and expatriate accounts. European Journal of Cross-Cultural Competence and Management, 2(1), 54-76. https://doi.org/10.1504/ejccm.2011.042677c

Soin, K., \& Scheytt, T. (2006). Making the case for narrative methods in cross-cultural 
organizational research. Organizational Research Methods, 9(1), 55-77. https://doi.org/10.1177/1094428105283297

Spencer, A. (2011). Americans create hybrid spaces in Costa Rica: A framework for exploring cultural and linguistic integration. Language and Intercultural Communication, 11(1), 59-74. https://doi.org/10.1080/14708477.2010.517847

Steers, R. M., Sanchez-Runde, C. J., \& Nardon, L. (2012). Culture, cognition, and managerial leadership. Asia Pacific Business Review, 18(3), 425-439. https://doi.org/10.1080/13602381.2011.640537

Taras, V., \& Gonzalez-Perez, M.-A. (Eds.). (2015). The Palgrave handbook of experiential learning in international business. New York, NY: Palgrave Macmillan UK. https://doi.org/10.1057/9781137467720

Taylor, S. J., \& Osland, J. S. (2011). The impact of intercultural communication on global organizational learning. In M. Easterby-Smith \& M. A. Lyles (Eds.), Handbook of organizational learning and knowledge management (2nd ed., pp. 579-604). Chichester, West Sussex: John Wiley \& Sons.

Templer, K. J., Tay, C., \& Chandrasekar, N. A. (2006). Motivational cultural intelligence, realistic job preview, realistic living conditions preview, and crosscultural adjustment. Group and Organization Management, 31(1), 154-173. https://doi.org/10.1177/1059601105275293

Thomas, D. C., Elron, E., Stahl, G., Ekelund, B. Z., Ravlin, E. C., Cerdin, J. L., ... Lazarova, M. B. (2008). Cultural intelligence: Domain and assessment. International Journal of Cross Cultural Management, 8(2), 123-143. https://doi.org/10.1177/1470595808091787

Tucker, M. F., Bonial, R., \& Lahti, K. (2004). The definition, measurement and prediction of intercultural adjustment and job performance among corporate expatriates. International Journal of Intercultural Relations, 28(3-4), 221-251. https://doi.org/10.1016/j.ijintrel.2004.06.004

Turner, Y. (2006). Students from mainland China and critical thinking in postgraduate business and management degrees: Teasing out tensions of culture, style and substance. International Journal of Management Education (Vol. 5). https://doi.org/10.1177/0266242610391936

Weick, K. E. (1995). Sensemaking in organizations. London: Sage.

Wong, M. M. L. (2001). Internationalizing Japanese Expatriate Managers:

Organizational Learning through International Assignment. Management Learning, 
32(2), 237-251. https://doi.org/10.1177/1350507601322005

Yamazaki, Y. (2010). Expatriate adaptation: A fit between skills and demands among Japanese expatriates in USA. Management International Review, 50(1), 81-108. https://doi.org/10.1007/s11575-009-0022-7

Yamazaki, Y., \& Kayes, D. C. (2004). An experiential approach to cross-cultural learning: A review and integration of competencies for successful expatriate adaptation. Academy of Management Learning and Education, 3(4), 362-379. https://doi.org/10.5465/AMLE.2004.15112543

Yamazaki, Y., \& Kayes, D. C. (2007). Expatriate learning: Exploring how Japanese managers adapt in the United States. International Journal of Human Resource Management, 18(8), 1373-1395. https://doi.org/10.1080/09585190701502521

Yan Lo-Philip, S. W., Carroll, C., Li Tan, T., Ann, O. Y., Heng Tan, Y., \& Hwee Seow, S. (2015). Transforming educational practices: Cultural learning for short-term sojourners. International Journal of Intercultural Relations, 49, 223-234. https://doi.org/10.1016/j.ijintrel.2015.10.006

Zhang, Y., Wei, X., \& Zhou, W. (2017). An asymmetric cross-cultural perspective on the mediating role of conflict management styles in expatriation. International Journal of Conflict Management, 28(5), 592-616. https://doi.org/10.1108/IJCMA06-2016-0052 